\title{
国内自発報告データベースを用いたデフェラシロクスと他剤の併用による 急性腎不全リスクのシグナル検出とケースコントロール研究による評価
}

\author{
水野貴仁 ${ }^{* 1}$, 梅村拓巳 ${ }^{1,2}$, 酒井隆全 ${ }^{3}$, 樑津昌弘 ${ }^{1}$, 山田哲也 ${ }^{1}$ \\ 梶口智弘 ${ }^{4}$, 田辺公一 ${ }^{2}$, 大津史子 ${ }^{2}$, 後藤伸之 ${ }^{2}$, 鷹見繁宏 ${ }^{1}$ \\ 公立陶生病院 薬剂部 ${ }^{1}$, 名城大学薬学部 ${ }^{2}$, 名城大学大学院薬学研究科 ${ }^{3}$, 公立陶生病院 血液腫瘍内科 ${ }^{4}$
}

\section{Signal Detection on the Concomitant Use of Deferasirox with other Drugs and Acute Renal Failure Using Data Mining of the Japanese Adverse Drug Event Report Database and Evaluation by a Case-control Study}

Takahito Mizuno $^{* 1}$, Takumi Umemura ${ }^{1,2}$, Takamasa Sakai ${ }^{3}$, Masahiro Fukatsu', Tetsuya Yamada', Tomohiro Kajiguchi', Kouichi Tanabe, ${ }^{2}$ Fumiko Ohtsu', Nobuyuki Goto ${ }^{2}$ and Shigehiro Takami ${ }^{1}$ Department of Pharmacy, Tosei General Hospital ${ }^{1}$, Faculty of Pharmacy, Meijo University ${ }^{2}$, Graduate School of Pharmacy, Meijo University ${ }^{3}$, Department of Hematology and Oncology, Tosei General Hospital ${ }^{4}$

$\left[\begin{array}{l}\text { Received April 8, } 2016 \\ \text { Accepted September 28, } 2016\end{array}\right]$

Little research has been published on the influence of deferasirox (DFX) (an iron chelating agent), or its use concomitantly with other drugs and acute renal dysfunction. We used signal detection to determine the risk of acute renal failure associated with DFX and concomitant drug use using the Japanese Adverse Drug Event Report database (JADER). When using the proportional reporting ratio (PRR) as an evaluation index, the following concomitant drugs were found by signal detection: DFX-cyclosporin A (CyA) (risk ratio associated with concomitant use: 2.53); DFXloxoprofen sodium (risk ratio associated with concomitant use: 2.48); DFX-diclofenac sodium (risk ratio associated with concomitant use: 3.31); DFX-amphotericin B (risk ratio associated with concomitant use: 2.88); DFX-anti-human thymocyte immunoglobulin (risk ratio associated with concomitant use: 2.13). When we used the reporting odds ratio (ROR) as an evaluation index, we found the concomitant usage risk of DFX-CyA (adjusted ROR: 24.9, 95\% confidence interval (CI): 14.8-42.0).

We found concomitant drugs using signal detection and evaluated them by performing a case-control study. We investigated cases that occurred between June 2008 and December 2014 at Tosei General Hospital in Aichi, Japan (701 beds). Of 29 total cases where DFX was administered, there were a higher number of cases where cyclosporine was administered concomitantly in the acute renal failure group compared with the group with no onset of acute renal failure (odds ratio: 16.00, 95\% CI: 1.58-162.10).

Our study suggests the possibility that the concomitant use of DFX and CyA might be associated with an increased risk of acute renal failure.

Key words — Japanese Adverse Drug Event Report database, deferasirox, cyclosporin A, myelodysplastic syndrome, aplastic anemia, acute renal failure

\section{緒言}

再生不良性貧血（aplastic anemia: AA），骨髄異 形成症候群 (myelodysplastic syndromes: MDS), $\beta$ サラセミア，鎌状赤血球貧血等の難治性貧血患 者にとって, 赤血球輸血（輸血）療法は予後およ び quality of life（QOL）の改善に不可欠な支持療
法である.しかし, 頻回の継続的な輸血により鉄 蓄積が進行すると細胞内の過㮃鉄により, 肝障害, 心障害, 糖尿病, 皮膚色素沈着等の種々の合併症 を引き起こし, 不可逆的な蔵器障害を生じ, 生命 予後が極めて不良となる。従来の注射製剤である デフェロキサミンによる治療の場合, 連日投与を 行わないと明瞭な治療効果が得られず, 外来受診

\footnotetext{
* 个489-8642＼cjkstart愛知県瀬戸市西追分町160
} 
時あるいは輸血時だけの投与では効果が不十分で

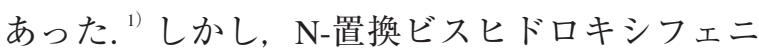
ルトリアゾールを含有する製剤で 1 日 1 回の経口 投与により鉄を効率的に除去できる鉄キレート剂 であるデフェラシロクス（DFX）が開発され， 質の高い治療の継続が容易となった。DFX は欧 州で 2002 年 3 月に初めて承認され，日本では未 承認薬使用問題検討会議において外国臨床デー夕 の活用も考慮したうえで，早期の承認申請が行わ れることが望まれると報告された，その後，海外 臨床試験成績並びに国内第 I 相臨床試験成績をま とめて，優先審査品目として 2008 年 4 月に「輸 血による慢性鉄過剰症（注射用鉄キレート剂治療 が不適当な場合)」を適応とした DFX を含有する エクジェイド®懸濁用錠が承認された. そのため, 日本人の安全性のデー夕は海外第 II 相臨床試験の 日本人サブグループ解析の学会報告にとどまり， 医薬品適正使用に必要な医薬品情報が十分に収 集・分析されているわけではない.

一方, DFXの主な副作用の 1 つに血清クレア チニン值上昇をはじめとした急性腎不全が知られ ており，国内第 I 相試験においては，継続投与で 血清クレアチニン増加は $28.6 \%$ に認められてい る.（エクジェイド®懸濁用錠医薬品インタビュー フォーム, ノバルティスファーマ株式会社, 1998 年 9 月作成，2016 年 7 月改訂）実際に我々も臨床 現場において薬剤師の提案により DFX導入となっ たものの，内服開始後血清クレアチニン值の大幅 な上昇により DFXが中止となった症例を複数経 験した。 その際，それらの症例について精査を行 い，併用している薬剤に共通する薬剤が見られた ため, 併用薬剤が影響している可能性を懸念しつ つも，DFXの併用薬剤に関する報告は極めて少な
く, 文献的情報としては, 比較対象が設定されて いない症例集積研究が存在するのみであったこと から，明確な結論を得ることができなかった。

そこで, 今回我々は, DFX と併用薬剤との急 性腎不全における関連性を見出すことを目的とし て，国内自発報告データベースを用いた研究およ びケースコントロール研究を行った.

\section{方 法}

\section{1. 併用薬牏による急性腎不全リスクのシグナル 検出}

\section{（1）検討に使用したデータベース}

本検討に使用した国内の副作用が疑われる症例の 自発報告データベースは, 独立行政法人医薬品医療 機器総合機構（PMDA）が提供する「医薬品副作 用データベース」Japanese Adverse Drug Event Report database（JADER）を PMDA の Web サイト（http:// www.info.pmda.go.jp/fukusayoudb/CsvDownload.jsp, 2015 年 12 月 18 日）より入手し, 2004 年 4 月〜 2015 年 3 月に PMDA に報告されたデー夕を用いた .

\section{（2）検討対象とした有害事象}

JADER は, 症例一覧テーブル, 医薬品情報テー ブル，副作用テーブルおよび原疾患テーブルの 4 つ のテーブルから構成されており，本検討では薬剤レ コードにおいて医薬品の関与が被疑薬とされたもの を解析対象とした. ${ }^{2-4)}$ 交絡の調整に用いるため, 性 別, 年代に欠損のある報告は本解析から除外した。

検討対象とした有害事象は, 急性腎不全とした。 対象有害事象の抽出には ICH 国際医薬用語集日 本語版（MedDRA/J, ver 18.0）の標準検索式 （Standardised MedDRA Queries: SMQ）を使用し た。対象とした SMQ には，表 1 に示した基本語

表 1 使用した Standardised MedDRA Queries（SMQ）とその基本語（preferred term: PT）

\begin{tabular}{|c|c|}
\hline 対象 SMQ & 基本語 \\
\hline 急性腎不全 & 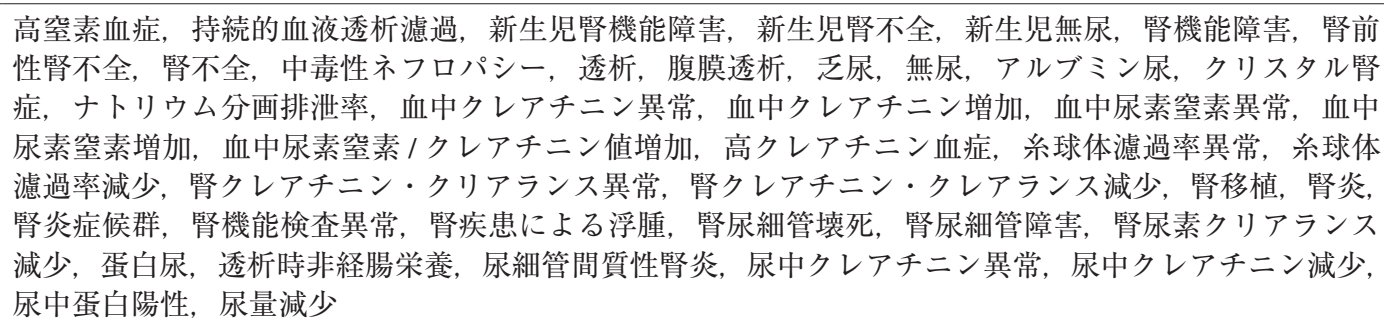 \\
\hline
\end{tabular}


（preferred term: PT）が含まれる.

\section{（3）薬剤併用リスクのシグナル検出方法}

薬剤併用リスクのシグナルを評価するために, 対象薬剂の使用による急性腎不全の発現につい て，「データマイニング手法の導入に関する検討 結果報告書 2007 年 3 月」（https://www.pmda.go.jp/ files/000148312.pdf, 2015 年 9 月 30 日）を参考に, 報告数を症例数ベースでカウントし，図 1 に示 す $2 \times 2$ クロス集計表を用いて以下の 2 つの評価 指標で解析を行った。
(1) proportional reporting ratio (PRR) 有害事象を検出するためのシグナル指標である PRR は, 図 1 に示す通り対象薬剤の対象有害事象 $\left(\mathrm{n}_{11}\right)$ および対象薬剤の全有害事象 $\left(\mathrm{n}_{1+}\right)$, 対象薬 剂以外の対象有害事象 $\left(\mathrm{n}_{21}\right)$ および対象薬剤以外 の全有害事象（ $\mathrm{n}_{2+}$ ) のリスク比であり, PRRにおけ る薬剤単剂のシグナル検出条件である報告症例数 $\left(\mathrm{n}_{11}\right)$ が 3 件以上, PRR が 2 以上, $\chi^{2}$ が 4 以上の全

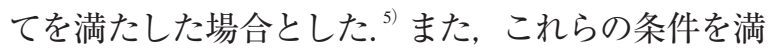
たした薬剤については併用リスク比を算出した. 併

$2 \times 2$ クロス集計表

\begin{tabular}{cccc}
\hline & $\begin{array}{c}\text { 対象 } \\
\text { 有害事象 }\end{array}$ & $\begin{array}{c}\text { 対象以外の } \\
\text { 有害事象 }\end{array}$ & 計 \\
\hline 対象薬剂 & $\mathrm{n}_{11}$ & $\mathrm{n}_{12}$ & $\mathrm{n}_{1+}$ \\
対象以外の薬剂 & $\mathrm{n}_{21}$ & $\mathrm{n}_{22}$ & $\mathrm{n}_{2+}$ \\
\hline 計 & $\mathrm{n}_{+1}$ & $\mathrm{n}_{+2}$ & $\mathrm{n}_{++}$ \\
\hline
\end{tabular}

PRR 算出式

$$
\begin{aligned}
& \text { PRR }=\frac{\mathrm{n}_{11} / \mathrm{n}_{1+}}{\mathrm{n}_{21} / \mathrm{n}_{2+}}=\frac{\mathrm{n}_{11} \mathrm{n}_{2+}}{\mathrm{n}_{21} \mathrm{n}_{1+}} \\
& \chi^{2}=\frac{\mathrm{n}_{++}\left(\left|\mathrm{n}_{11} \mathrm{n}_{22}-\mathrm{n}_{12} \mathrm{n}_{21}\right|-\mathrm{n}_{++} / 2\right)^{2}}{\mathrm{n}_{1+} \mathrm{n}_{2+} \mathrm{n}_{+1} \mathrm{n}_{+2}}
\end{aligned}
$$

シグナル検出条件

(1) $\mathrm{n}_{11} \geqq 3 \quad$ (2) PRR $\geqq 2 \quad$ (3) $\chi^{2} \geqq 4$

併用リスク比 $=\frac{\text { PRR }_{\text {DrugA-B }}}{\text { PRR }_{\text {DrugA }}}$

DrugA：DFX または併用薬剤における PRRの大きい方

DrugB : DFX または併用薬剤における PRRの小さい方

\section{$R O R$ 算出式}

$$
\mathrm{ROR}=\frac{\mathrm{n}_{11} / \mathrm{n}_{12}}{\mathrm{n}_{21} / \mathrm{n}_{22}}=\frac{\mathrm{n}_{11} \mathrm{n}_{22}}{\mathrm{n}_{12} \mathrm{n}_{21}}
$$

95\%CI 算出式

$$
95 \% \mathrm{CI}=\exp \left[\log (\mathrm{ROR}) \pm 1.96 \sqrt{\left(1 / \mathrm{n}_{11}\right)+\left(1 / \mathrm{n}_{12}\right)+\left(1 / \mathrm{n}_{21}\right)+\left(1 / \mathrm{n}_{22}\right)}\right]
$$

\section{調整 ROR 算出式}

$\operatorname{logROR}=\beta 1+\beta 2 *$ age $+\beta 3 *$ sex $+\beta 4 *$ dfx $*$ drug

図 1 併用薬剤のリスク評価方法および算出方法

併用薬郕による急性腎不全リスクのシグナル検出で用いる proportional reporting ratio（PRR） および reporting odds ratio（ROR）の算出方法を示す. 
用リスク比の指標は, 対象薬剤ごとのPRRに対する, 併用時の PRR の比であり, 併用時のシグナル検出 条件はその比が 2 を超える場合とした ${ }^{2,3)}$

(2) reporting odds ratio（ROR）

RORの算出には $2 \times 2$ クロス集計表を用いた.さ らに，過去の報告 ${ }^{5,6)}$ に基づき，性別と年代を調 整したROR（調整ROR）を算出した（図 1）.

検出基準は併用時の調整 ROR が DFX と対象薬 剂単剂に打けるそれぞれの調整 ROR より高い，か つ併用時の調整 ROR における 95\% 信頼区間 (CI) がDFX と対象薬剤単哓におけるそれぞれの調整 RORに抢ける $95 \%$ CI と重ならない場合とした。

\section{（4）検討対象とした併用薬剤の選択基準}

PRRにおいて一般的なシグナル検出条件の 1 つである報告症例数 $\left(\mathrm{n}_{11}\right)$ が 3 件以上であるため, 被疑薬として DFX とともに報告されている薬剤 のうち, DFX との併用事例が報告数 3 件以上の 薬剤を検討対象とした。

\section{2. ケースコントロール研究によるシグナル検出 された併用薬剤の評価}

（1）対象患者

地域がん診療連携拠点病院の指定を受けている 公立陶生病院（701 床）において, DFXが上市 された 2008 年 6 月〜2014 年 12 月の期間に DFX が投与された全症例を対象とした。そのうち急性 腎不全を発症した症例をケース群，非発症例をコ ントロール群とした，急性腎不全の定義は急性腎 障害のための KDIGO 診療ガイドライン ${ }^{7)}$ をい, DFX 投与中に血清クレアチニン值が投与開始時 の 1.5 倍以上の上昇もしくは $0.3 \mathrm{mg} / \mathrm{dL}$ 以上の上 昇および 6 時間以上にわたって尿量が $0.5 \mathrm{~mL} / \mathrm{kg} / \mathrm{hr}$ に満たない場合のいずれかとした。なお，敗血症 や低血圧, 横紋筋融解症, 術後, 人工呼吸器装着 下など，すでに急性腎不全のリスク下にある症例 ${ }^{8}$ は除外した。

\section{（2）調査項目}

診療記録より後方視的に以下の項目を調査した。 年齢，性別，DFX 投与量，DFX 投与開始時の血 清フェリチン值, 総赤血球輸血単位数, 血清クレ アチニン值掞よびアスパラギン酸アミノ基転移酵 素 (aspartate aminotransferase: AST)，アラニンア
ミノ基転移酵素 (alanine aminotransferase: ALT), 輸血を必要とする目的疾患, 基礎疾患として急性 腎不全のリスク因子と報告されている糖尿病, 慢 性腎不全, 心不全, 肝不全, 低蛋白血症および動 脈の疾患の有無, ${ }^{8)}$ さらに DFX 開始時の併用薬剂 について調查した。 なお, 目的疾患の重症度分類 については, MDS は International prognostic scoring system（IPSS）に従い，Low および Intermediate-1 を低リスク， Intermediate-2 および High を高リス クに分類した。 ${ }^{9}$ また， AA は再生不良性貧血診療 の参照ガイドに従い分類した. ${ }^{10)}$

なお，併用薬剤においては前述のシグナル検出 において PRR もしくはROR のいずれかで併用リ スクのシグナルが検出された薬剤を対象とし, ケース群については発症時の併用薬片, コント ロール群については投与開始後 2 力月以内の併用 薬荗の有無を調査した。なお，疾患名については 国際疾病分類 (ICD-10)（http://www.dis.h.u-tokyo. ac.jp/byomei/icd10/http://www.dis.h.u-tokyo.ac.jp/ byomei/icd10/，2015 年 9 月 30 日）に準拠した.

（3）統計解析方法

急性腎不全発症の有無で対象症例を 2 群に分類 し, ほかの調査項目について連続変数は Student's $t$-test または Mann-Whitney $U$-test, カテゴリカル データは $\chi^{2}$ 検定または Fisher's exact testを行い各 群間の独立性を検討した。 $P<0.1$ となった項目 については交絡要因を調整するために多変量ロジ スティック回帰分析を行った.

統計解析はSPSS Statistics ${ }^{\circledR}$ ver 21 (日本IBM(株), 東京）を用い,いずれも $P<0.05$ を有意水準とした。

\section{（4）倫理的配慮}

本研究は「人を対象とする医学系研究に関する 倫理指針」を遵守して実施し, 公立陶生病院医の 倫理委員会の承認（受付番号 539）を得て実施した.

\section{結果}

\section{1. 併用薬剤による急性腎不全リスクのシグナル 検出}

解析対象期間の JADER のの総登録件数は 353,988 件であり，このうち性別および年代に欠 損のあったものを除いた報告件数は 330,212 件 
（93.3\%）であった。そのうち対象とした有害事 象の急性腎不全の報告件数は, 13,212 件であっ た.さらにこのなかで DFXが被疑薬とされてい る報告件数は 151 件であり，急性腎不全の被疑薬 として解析対象となった薬剤とその報告数はシク ロスポリン（cyclosporin A: CyA）が 619 件と最 も多く, 次にロキソプロフェンナトリウム 555 件 が続いた。

表 2 には急性腎不全における，DFX および対象 薬剂の全報告および DFX との併用時の報告件数 $\left(\mathrm{n}_{11}\right), \mathrm{PRR}, \chi^{2}$, 併用リスク比を示した. DFX との 併用のうち, シグナル検出された薬剤の組み合わ せは, DFX-CyA（併用リスク比：2.53）, DFX-ロキ ソプロフェンナトリウム（併用リスク比：2.48）, DFX-ジクロフェナクナトリウム（併用リスク比： 3.31), DFX-アムホテリシン B（併用リスク比：2.88） および DFX- 抗胸腺 G（併用リスク比：2.13）で あった

また，表 3 には DFX 単剤および各対象薬剤との 併用における ROR および調整 ROR を示した，基

表 2 急性腎不全のシグナルとデフェラシロクスに対する併用リスク比

\begin{tabular}{|c|c|c|c|c|c|c|c|}
\hline \multirow{2}{*}{ 被疑薬 } & \multicolumn{3}{|c|}{ 全報告 } & \multicolumn{3}{|c|}{ "デフェラシロクス併用 } & \multirow{2}{*}{$\begin{array}{c}\text { 併用 } \\
\text { リスク比 }\end{array}$} \\
\hline & $\mathrm{n}_{11}$ & PRR & $\chi^{2}$ & $\mathrm{n}_{11}$ & PRR & $\chi^{2}$ & \\
\hline デフェラシロクス & 151 & 5.03 & 498.14 & - & - & - & - \\
\hline シクロスポリン & 619 & 3.5 & 1095.97 & 29 & 12.74 & 314.05 & 2.53 \\
\hline ロキソプロフェンナトリウム & 555 & 3.06 & 767.64 & 2 & 12.50 & 11.69 & 2.48 \\
\hline タクロリムス & 439 & 1.75 & 141.78 & 2 & 10.00 & 8.80 & - \\
\hline ジクロフェナクナトリウム & 317 & 2.84 & 381.41 & 2 & 16.66 & 16.53 & 3.31 \\
\hline プレドニゾロン & 233 & 0.56 & 82.79 & 1 & 3.12 & 0.11 & - \\
\hline レボフロキサシン & 189 & 1.65 & 49.03 & 0 & 0.00 & 0.75 & - \\
\hline アムホテリシン B & 186 & 5.21 & 645.04 & 3 & 15.00 & 27.54 & 2.88 \\
\hline スルファメトキサゾール / トリメトプリム & 152 & 2.19 & 100.54 & 1 & 3.57 & 0.18 & 0.71 \\
\hline イマチニブメシル酸塩 & 113 & 0.90 & 1.14 & 0 & 0.00 & 1.25 & - \\
\hline レナリドミド & 104 & 1.62 & 25.02 & 1 & 5.00 & 0.47 & - \\
\hline 抗ヒト胸腺細胞免疫グロブリン & 75 & 1.34 & 6.35 & 3 & 10.71 & 18.33 & - \\
\hline ボリコナゾール & 74 & 2.50 & 67.29 & 1 & 6.25 & 0.75 & 1.24 \\
\hline アザシチジン & 72 & 1.30 & 4.91 & 1 & 1.92 & 0.00 & - \\
\hline フルコナゾール & 56 & 4.54 & 156.93 & 1 & 6.25 & 0.75 & 1.24 \\
\hline メテノロン & 7 & 3.72 & 11.82 & 3 & 9.37 & 15.47 & 1.86 \\
\hline
\end{tabular}

PRR: proportional reporting ratio

表 3 デフェラシロクスおよび併用被疑薬における急性腎不全の調整 reporting odds ratio（ROR）

\begin{tabular}{|c|c|c|c|c|c|c|}
\hline \multirow{2}{*}{ 被疑薬 } & \multicolumn{3}{|c|}{ 全報告 } & \multicolumn{3}{|c|}{ "デフェラシロクス併用 } \\
\hline & $\mathrm{n}_{11}$ & 調整 $\mathrm{ROR}^{\mathrm{a})}$ & $\left(95 \% \mathrm{CI}^{\mathrm{b})}\right)$ & $\mathrm{n}_{11}$ & 調整 ROR & $(95 \% \mathrm{CI})$ \\
\hline デフェラシロクス & 151 & 5.5 & $(4.6-6.6)$ & - & - & \\
\hline シクロスポリン & 619 & 4.5 & $(4.1-4.9)$ & 29 & 24.9 & $(14.8-42.0)$ \\
\hline ロキソプロフェンナトリウム & 555 & 3.5 & $(3.2-3.8)$ & 2 & 21.4 & $(3.0-152.5)$ \\
\hline タクロリムス & 439 & 2.1 & $(1.9-2.3)$ & 2 & 16.4 & $(2.7-99.4)$ \\
\hline ジクロフェナクナトリウム & 317 & 3.1 & $(2.7-3.5)$ & 2 & 48.0 & $(4.4-529.3)$ \\
\hline プレドニゾロン & 233 & 0.6 & $(0.5-0.7)$ & 1 & 3.2 & $(0.4-26.2)$ \\
\hline レボフロキサシン & 189 & 1.7 & $(1.5-2.0)$ & 0 & - & \\
\hline アムホテリシン B & 186 & 6.4 & $(5.4-7.5)$ & 3 & 33.9 & $(5.6-204.9)$ \\
\hline スルファメトキサゾール / トリメトプリム & 152 & 2.3 & $(2.0-2.7)$ & 1 & 4.3 & $(0.5-36.2)$ \\
\hline イマチニブメシル酸塩 & 113 & 0.9 & $(0.7-1.1)$ & 0 & - & \\
\hline レナリドミド & 104 & 1.5 & $(1.2-1.9)$ & 1 & 4.9 & $(0.5-44.0)$ \\
\hline 抗ヒト胸腺細胞免疫グロブリン & 75 & 1.5 & $(1.2-2.0)$ & 3 & 18.8 & $(4.2-84.7)$ \\
\hline ボリコナゾール & 74 & 2.4 & $(1.9-3.1)$ & 1 & 9.2 & $(0.9-90.0)$ \\
\hline アザシチジン & 72 & 1.1 & $(0.9-1.4)$ & 1 & 1.7 & $(0.2-12.8)$ \\
\hline フルコナゾール & 56 & 5.2 & $(3.9-6.9)$ & 1 & 8.2 & $(0.9-80.0)$ \\
\hline メテノロン & 7 & 3.8 & $(1.7-8.7)$ & 3 & 13.4 & $(3.2-56.1)$ \\
\hline
\end{tabular}

a) 年代，性別で調整. b ) $95 \%$ confidence interval. 
準を満たした併用薬剤の組み合わせは DFX-CyA の みであった（調整 ROR：24.9, 95\%CI：14.8-42.0).

\section{2. ケースコントロール研究によるシグナル検出 された併用薬剤の評価}

対象期間における DFX 使用症例数は 29 例で, 男性 17 例，女性 12 例，年齢は $70.7 \pm 12.0 （$ Mean 土SD）歳であった。そのうち急性腎不全発現症 例は 7 例で，いずれも血清クレアチニン值の上昇 によるものであった。また， 7 例中 6 例は DFX の投与中止となり，1 例が用量減量となっていた。

また結果 1。併用薬荗による急性腎不全リスク のシグナル検出より, 以降における併用薬剤の調 査は CyA，ロキソプロフェンナトリウム，ジク
ロフェナクナトリウム，アムホテリシン B およ び抗胸腺 $\mathrm{G}$ とした．表 4 には急性腎不全群およ び非急性腎不全群における各調查項目の内訳を示 した，両群間に差が認められた項目は併用薬剤の CyA（オッズ比 $16.00 ， 95 \%$ CI : 1.58-162.10）の みであり，急性腎不全発現症例 7 例中 6 例に使用 されていた．ほかの項目については両群間に統計 学的差は認められなかった. $P<0.1$ となった項 目は 1 項目のみであったため, 多変量ロジスティッ ク回帰分析は実施しなかった。また, DFX と CyAを併用していた12症例の詳細を示した(表5). 12 症例中 10 症例が再生不良性貧血であり，急性 腎不全発症群の CyA トラフ濃度は 88.0〜 354.0 ng/ $\mathrm{mL}$ ，非発症群では $150.6 \sim 418.4 \mathrm{ng} / \mathrm{mL}$ であった.

表 4 デフェラシロクス投与患者における患者背景

\begin{tabular}{|c|c|c|c|c|}
\hline & 項目 & $\begin{array}{c}\text { 急性腎不全群 } \\
n=7\end{array}$ & $\begin{array}{c}\text { 非急性腎不全群 } \\
\mathrm{n}=22\end{array}$ & $P$ 值 \\
\hline 性別（男 & & 5 & 12 & $0.665^{\mathrm{b})}$ \\
\hline 年齢a)（歳 & & $71.1 \pm 6.0$ & $70.6 \pm 13.5$ & $0.911^{c)}$ \\
\hline 65 歳以上 & & 6 & 15 & $0.635^{b)}$ \\
\hline デフェラ & ロクス投与量 ${ }^{a)}(\mathrm{mg} / \mathrm{kg}$ ) & $6.5 \pm 2.4$ & $7.2 \pm 3.3$ & $0.628^{c)}$ \\
\hline $5 \mathrm{mg} / \mathrm{kg}$ 末 & & 2 & 7 & - \\
\hline $5 \sim 10 \mathrm{mg} /$ & 未満 & 5 & 11 & - \\
\hline $10 \sim 20 \mathrm{mg}$ & & 0 & 4 & - \\
\hline 血清フェ & ンン值 a) ( $\mu \mathrm{g} / \mathrm{dL})$ & $1694.0 \pm 904.8$ & $1692.7 \pm 682.4$ & $0.404^{c)}$ \\
\hline 総赤血球車 & 1単位数 a) (単位) & $34.3 \pm 18.2$ & $42.5 \pm 39.84$ & $0.607^{c)}$ \\
\hline 血清クレ & ニン值 a) (mg/dL) & $0.93 \pm 0.34$ & $0.83 \pm 0.52$ & $0.682^{d)}$ \\
\hline $\operatorname{AST}^{a)}(\mathrm{IU}$ & & $19.1 \pm 9.1$ & $27.4 \pm 16.2$ & $0.665^{\mathrm{d})}$ \\
\hline $\operatorname{ALT}^{\mathrm{a})}(\mathrm{IU}$ & & $28.0 \pm 13.5$ & $27.5 \pm 21.4$ & $1.000^{\mathrm{d})}$ \\
\hline & 骨髄異形成症候群 & & & \\
\hline & 低リスク & 2 & 9 & $0.677^{\mathrm{e})}$ \\
\hline 目的疾串 & 高リスク & 1 & 3 & $1.000^{\mathrm{e})}$ \\
\hline 日的垁忠 & 再生不良性貧血 & & & \\
\hline & 軽症から中等症 & 0 & 2 & - \\
\hline & 重症から最重症 & 4 & 5 & $0.158^{\mathrm{e})}$ \\
\hline & 糖尿病 & 2 & 3 & $0.569^{\mathrm{e})}$ \\
\hline & $\mathrm{HbA1c} 7.0$ 以上 & 1 & 1 & $0.431^{\mathrm{e})}$ \\
\hline & $\mathrm{HbA1c}$ 測定なし & 1 & 2 & - \\
\hline & 慢性腎不全 & 0 & 1 & - \\
\hline 其碄疾串 & 心不全 & 0 & 2 & - \\
\hline 基礎次忠 & 肝不全 & 0 & 1 & - \\
\hline & 低蛋白血症 & 2 & 3 & $0.569^{\mathrm{e})}$ \\
\hline & 血清蛋白質 4.0 $5.0 \mathrm{~g} / \mathrm{dL}$ & 1 & 1 & $0.431^{\mathrm{e})}$ \\
\hline & 血清蛋白質 5.0 6.0 g/dL & 1 & 2 & $1.000^{\mathrm{e})}$ \\
\hline & 動脈の疾患 & 0 & 2 & - \\
\hline & シクロスポリン & 6 & 6 & $0.011^{\mathrm{b})}$ \\
\hline & ロキソプロフェンナトリウム & 1 & 1 & $0.431^{\mathrm{e})}$ \\
\hline 併用薬剂 & 抗ヒト胸腺細胞免疫グロブリン & 1 & 1 & $0.431^{\mathrm{e})}$ \\
\hline & アムホテリシン B & 1 & 1 & $0.431^{\mathrm{e})}$ \\
\hline & ジクロフェナクナトリウム & 0 & 0 & - \\
\hline
\end{tabular}

a) Mean $\pm \mathrm{SD}$, b) $\chi^{2}$ 検定, c) Student's $t$-test, d) Mann-Whitney $U$-test, e) Fisher's exact test. AST：アスパラギン酸ア ミノ基転移酵素, ALT : アラニンアミノ基転移酵素. 
表 5 デフェラシロクスとシクロスポロリン併用 12 症例の詳細

\begin{tabular}{|c|c|c|c|c|c|c|c|c|c|}
\hline $\begin{array}{l}\text { 症例 } \\
\text { No. }\end{array}$ & 性別 & $\begin{array}{l}\text { 年齢 } \\
\text { (歳) }\end{array}$ & 疾患 & $\begin{array}{l}\text { DFX 開始時 } \\
\mathrm{SCr}(\mathrm{mg} / \mathrm{dL})\end{array}$ & $\begin{array}{c}\text { DFX 投与量 } \\
(\mathrm{mg} / \mathrm{kg})\end{array}$ & $\begin{array}{l}\text { 急性腎不全発症 } \\
\text { までの期間 (日) }\end{array}$ & $\begin{array}{c}\text { CyA 開始量 } \\
(\mathrm{mg} / \mathrm{d})\end{array}$ & $\begin{array}{c}\text { CyA 投与量 }{ }^{a)} \\
(\mathrm{mg} / \mathrm{d})\end{array}$ & $\begin{array}{c}\left.\text { CyA トラフ濃度 }{ }^{a}\right) \\
(\mathrm{ng} / \mathrm{mL})\end{array}$ \\
\hline 1 & 男性 & 66 & AA & 1.46 & 9.5 & 71 & 100 & 200 & 245.0 \\
\hline 2 & 女性 & 80 & $\mathrm{AA}$ & 0.62 & 8.3 & 非発症 & 250 & 200 & 370.4 \\
\hline 3 & 女性 & 79 & $\mathrm{AA}$ & 1.02 & 9.4 & 非発症 & 200 & 250 & 168.0 \\
\hline 4 & 女性 & 68 & MDS & 0.62 & 9.5 & 21 & 150 & 150 & 88.0 \\
\hline 5 & 女性 & 69 & $\mathrm{AA}$ & 0.85 & 9.7 & 253 & 300 & 250 & 354.0 \\
\hline 6 & 男性 & 81 & $\mathrm{AA}$ & 0.68 & 7.7 & 75 & 250 & 200 & 204.0 \\
\hline 7 & 男性 & 75 & MDS & 1.26 & 5.9 & 62 & 300 & 175 & 192.5 \\
\hline 8 & 男性 & 75 & AA & 1.05 & 5.1 & 33 & 250 & 150 & 242.0 \\
\hline 9 & 男性 & 82 & $\mathrm{AA}$ & 1.18 & 4.0 & 非発症 & 250 & 150 & 150.6 \\
\hline 10 & 女性 & 61 & $\mathrm{AA}$ & 0.69 & 6.8 & 非発症 & 200 & 225 & 418.4 \\
\hline 11 & 女性 & 70 & $\mathrm{AA}$ & 0.81 & 9.9 & 非発症 & 50 & 未測定 & 未測定 \\
\hline 12 & 女性 & 65 & $\mathrm{AA}$ & 0.55 & 5.8 & 非発症 & 250 & 200 & 164.0 \\
\hline
\end{tabular}

DFX : デフェラシロクス, CyA：シクロスポリン, SCr：血清クレアチニン, MDS：骨䯣異形成症候群, AA：再生不良性貧血. a）急 性腎不全発症症例は発症時の值, 非発症症例は調查期間の最大值を示した。

\section{考察}

日々の病棟薬剤業務のなかで，薬物療法の質的 向上を目的としてクリニカルクエスチョンを見つ けていくことは臨床薬羭師の役割である。さらに その問題解決していくためリサーチクエスチョン に展開し, 臨床研究を実施し, 臨床現場に還元で きるエビデンスを構築することは極めて意義深 い. 本研究において DFX 内服患者における併用 薬剂と急性腎不全の関連性が疑われる症例を経験 したが，文献的情報からだけでは明確な結論を得 ることができなかった。薬凨による有害事象の因 果関係を判断する基準として国際医学団体協議会 (Council for International Organizations of Medical Science: CIOMS） VI ーキンググループは，Hill の基準をより実用的にした因果関係の判断材料を 提案している. ${ }^{11}$

本研究は個別症例に基づくクリニカルクエス チョンを基に，症例集積の検討として有害事象自 発報告データベースである JADER を用いて DFX と併用薬剂による急性腎不全リスクのシグナル検 出を行った。

有害事象のシグナル検出手法としては幾つかの 方法が存在するが, 今回我々はすでに薬郕併用リ スク検出について報告のある PRR および ROR に よる検討を行った. 本研究の結果から, DFX と の薬剂相互作用における急性腎不全発症に関し て, 両検討方法においてシグナル検出された
DFX と CyA の併用はリスク上昇に影響すること が強く示唆された（表 2，3）。また，ロキソプロ フェンナトリウム，ジクロフェナクナトリウム， アムホテリシン $\mathrm{B}$ および抗胸腺 $\mathrm{G}$ は $\mathrm{DFX}$ との併 用において PRRによる検討のみでシグナル検出 され（表 2)，リスク上昇の可能性が示唆された. 今回の検討では，抽出された薬剤において同様の 適応症を有する薬剤に偏りが見られた。その理由 としては DFX を使用する疾患は限られているた めと考えられる。

JADER をはじめ, 有害事象自発報告データベー スには, 過小報告や安全性情報, 市場動向の影響 を受けやすいといった報告バイアスがあること ${ }^{12)}$ など幾つか問題もあり, 結果の解釈には十分な注 意が必要である。また，PRR および ROR を使用 した併用リスクの算出手法は近年報告されている ものであること，「第 2 期医薬安全性研究会 第 15 回定例会 2014 年 11 月 8 日医薬品副作用デー夕 ベース JADER を用いた薬物相互作用解析 ——般 化線形モデルを用いたアプローチー」（https:// biostat.jp/archive_teireikai_2.php, 2016 年 9 月 26 日） においても，Thakrar BTらの報告 ${ }^{13)}$ で支持され る相加作用モデル（additive model）にあたると されていることから今回の検討はこれらの手法を用 いた. しかしながら, 有害事象自発報告データベー スを用いた薬物相互作用の解析について確立した 手法はなく，これらに関する妥当性，有用性につい ては十分な検討が必要とされている，そのため併 
用リスクのない薬剤がシグナル検出された可能性 は否定できず，結果の解釈には注意が必要と考え られる。 世界保健機関（World Health Organization: WHO）は，シグナルとは「それまで知られなかっ たか，もしくは不完全にしか立証されていなかっ た薬剤と有害事象との因果関係の可能性に関す る,さらに検討が必要な情報」と定義している. ${ }^{14)}$ また, CIOMS は, 有害事象自発報告データベース の統計的解析は慎重かつ適切な臨床的判断に代わ るものではないと示し，その限界に留意したうえ で，自発報告システムに基づく有害事象の評価の 必要性や重要性について明示している. ${ }^{15)}$ すなわ ち, 有害事象自発報告データベースを用いたシグ ナル検出はリスク仮説の段階であり，それらをさ らなる検討により評価する必要がある。そこで, 我々はさらにケースコントロール研究を行った。

その結果, 我々の研究によって DFX と CyAの 併用により急性腎不全のリスク上昇を示唆するこ とが明らかとなった（表 4)。このことは，治療 上 CyA の内服が必要な患者にとって, DFX の開 始や増量を検討するにあたって重要な情報である ことを示唆する. DFX と CyA の併用による急性 腎不全のリスク上昇に関して, 学会報告はあるも のの, いずれも比較対象が設定されていない症例 集積研究の段階であり, 本研究はケースコント ロール研究として比較対象を設定し検証した点が これまでの研究と大きく異なる，また，その他薬 剤については，今のところ症例報告も行われては いない，そのため，本研究によって新たな情報の 構築につながったといえる.

DFX と CyA の併用については, DFX の弱い CYP3A4 誘導作用により, CyA の代謝が促進さ れ作用が減弱するおそれがあるとされているが, 併用による急性腎不全の可能性に関しての記載は ない.（エクジェイド®懸濁用錠医薬品インタ ビューフォーム, ノバルティスファーマ株式会社, 1998 年 9 月作成, 2016 年 7 月改訂）DFX の急性 腎不全が起こる正確な機序は現状明らかになって はいないが，ミトコンドリアの機能抑制とATP の枯渴による尿細管上皮細胞に対する直接的な細 胞毒性，鉄の急速な枯渴による腎血流の減少，尿 細管細胞内でフリーの鉄が生じることによる急性
腎不全の誘発などの仮説が幾つかの文献で述べら れている. ${ }^{16,17)}$ 一方で, カルシニューリン阻害薬 である CyA は輸入細動脈等の腎血管収縮により 血流量の低下を引き起こすといわれている. ${ }^{18)} こ$ れにはプロスタグランジン（ $\mathrm{E}_{2}$ や $\mathrm{I}_{2} ）$ 産生低下, エンドセリン産生克進や一酸化窒素合成能低下な どがかかわるとされる. ${ }^{19,20)}$ さらに, 血管内皮細 胞障害 (血栓性微小血管障害), 尿細管機能障害 や尿細管間質線維化，その他活性酸素のようなフ リーラジカルや細胞内カルシウム濃度などの因子 が関与し, 使用直後のみならず長期使用によって 起こりうるともいわれている. ${ }^{21,22)}$ また，代謝機 構においてDFX はグルクロン酸抱合体および DFX 自身の胆汁排泄に multidrug resistance-associated protein 2（MRP2）を介する能動輸送が関与する ことが示唆されている（http://www.pmda.go.jp/ drugs/2008/P200800018/index.html, 2016 年 2 月 26 日). 一方で CyA は MRP2 で輸送はされないもの

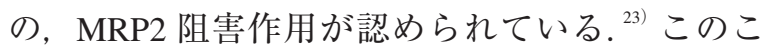
とから, CyA の併用下に押いて DFX の排泄遅延 を招くことで, 急性腎不全の相乗的なリスク上昇 の可能性が推察されるが, 明確な機序は不明であ る.また，DFXは通常用量である $20 \mathrm{mg} / \mathrm{kg} よ り$ 低用量であっても急性腎不全が発現しており（表 4), さらに DFX と CyA を併用していた 12 症例 において, 急性腎不全の発現症例は非発現症例に 比較して CyA のトラフ濃度が著しく高い傾向は認 められなかった（表 5)。 よって DFX と CyA を併 用する際はそれらの投与量・トラフ濃度にかかわ らず急性腎不全発現に注意が必要と考えられた。

DFX の使用症例数は多くない背景から今回は ケースコントロール研究によるリスク要因の解析 を行った．今回の研究は単施設の後方視的な検討 であり, 症例数が少数であることから併用薬剤の 検討が十分でない可能性が考えられる，特に，ジ クロフェナクナトリウムに関してはPRRにおい てシグナルが検出されたものの, 今回の対象症例 において該当はなく，本研究では検討ができな かった，今後はさらに症例を集めるために，多施 設またはより長期間の観察を行い, クレアチニン クリアランスや系球体濾過量（GFR）の評価な どより詳細な検討が必要と考えられた。 
国内外において優先審査品目として製造販売承 認されたDFX は，十分な医薬品情報が集積され た医薬品とはいい難い. 本研究結果はDFX と CyA の併用が急性腎不全リスクの上昇に関連する より高いエビデンスレベルの構築につながった.

\section{利益相反}

開示すべき利益相反はない.

\section{引用文献}

1) Takatoku M, Uchiyama T, Okamoto S, Kanakura $Y$, Sawada K, Tomonaga M, Nakao S, Nakahata T, Harada M, Murate T, Ozawa K, and Japanese National Research Group on Idiopathic Bone Marrow Failure Syndromes, Retrospective nationwide survey of Japanese patients with transfusion-dependent MDS and aplastic anemia highlights the negative impact of iron overload on morbidity/mortality, Eur J Haematol, 2007, 78, 487-494.

2）須々田寛, 高橋行雄, 重篤な薬疹を引き起こす薬 剂相互作用の探索, 薬剂度学, 2014, 19, 39-49.

3）野口義紘, 江崎宏樹, 浅野陽子, 横井貴文, 臼井 一将, 加藤未紗, 斎藤康介, 舘 知也, 寺町ひとみ, 日本の有害事象自発報告データベース (JADER) を用いたアンジオテンシン受容体拮抗薬, サイ アザイド系利尿薬併用療法において利尿薬が血 中カリウム值, 血中ナトリウム值へ与える影響 の解析, 医療薬学, 2015, 41, 488-496.

4）畑 武生, 濱田 武, 鈴木 薰, 西原雅美, 勝間田 敬弘, 国内の医薬品副作用データベース (JADER) を用いたデータマイニングによる抗精神病薬が 関連した体重増加の性差および年齢差の解析, 日本病院薬剤師会雑誌, 51, 411-415.

5) van Puijenbroek EP, Bate A, Leufkens HG, Lindquist M, Orre R, EGberts AC, A comparison of measures of disproportionality for signal detetection in spontaneous reporting system for adverse drug reactions, Pharmacoepidemiol Drug Saf, 2002, 11, 3-10.

6) Li H, Deng J, Yue Z, Zhang Y, Sun H, Detecting drug-herbal interaction using a spontaneous reporting system database: an example with benzylpenicillin and qingkailing injection, Eur J Clin Pharmacol, 2015, 71, 1139-1145.

7) KDIGO Clinical Practice Guideline for Acute Kid- ney Injury, Kidney International Supplements, 2012, 2, 19-36.

8) Leblanc M, Kellum JA, Ginbney RT, Lieberthal W, Tumlin J, Mehta R, Risk factors for acute renal failure : inherent and modifiable risks, Curr Opin Crit Care, 2005, 11, 533-536.

9) Greenberg P, Cox C, LeBeau MM, Fenaux P, Morel P, Sanz G, Sanz M, Vallespi T, Hamblin T, Oscier D, Ohyashiki K, Toyama K, Aul C, Mufti G, Bennett J, International scoring system for evaluating prognosis in myelodysplastic syndromes, Blood, 1997, 89, 2079-2088.

10）中尾眞二, 浦部晶夫, 別所正美, 大屋敷一馬, 大橋 春彦, 小島勢二, 月本一郎, 寺村正尚, 小峰光博, 再生不良性貧血診療の参照ガイド, 臨床血液, 2006, 47, 27-46.

11) Council for International Organizations of Medical Sciences Working Group VI, "Management of Safety Information from Clinical Trials -Report of CIOMS Working Group VI”, Geneva, 2005, pp 275-277.

12) Poluzzi E, Raschi E, Moretti U, De Ponti F, Drug induced torsades de points: data mining of the public version of the FDA Adverse Event Reporting System, Pharmacoepidemiol Drug Saf, 2009, 18, 512518.

13) Thakrar BT, Grundschober SB, Doessegger L, Detecting signals of drug-drug interactions in a spontaneous reports database, Br J Clin Pharmacol, 2007, 64, 489-495.

14) Edwards IR, Lindquiat M, Wiholm B-E, Napke E, Quality criteria for early signals of possible adverse drug reaction, Lancet, 1990, 336, 156-158.

15）〈すりの適正使用協議会監訳, ファーマコビジ ランスにおけるシグナル検出の実践, レーダー 出版センター, 東京, 2011, pp1-10.

16) Bhandari $S$, Galanello $R$, Renal aspects of thalassaemia a changing paradigm, Eur J Haematol, 2012, 89, 187-197.

17) Sánchez-González PD, López-Hernandez FJ, Morales AI, Macías-Nuñez JF, López-Novoa JM, Effects of deferasirox onrenal function and renal epithelial cell death, Toxicol Lett, 2011, 203, 154-161.

18）玄番宗一, 薬物による腎機能障害の病態と発生 機序, 日本薬理雑誌, 2006, 127, 433-440.

19) Benigni A, Morigi M, Perico N, Zoja C, Amuchastegui CS, Piccinelli A, Donadelli R, Remuzzig, The acute effect of FK506 and cyclosporine on endothelial cell function and renal vascular resistance, Transplanta- 
tion, 1992, 54, 775-780.

20) Moutabarrik A, Ishibashi M, Fukunaga M, Kameoka H, Kawaguchi N, Takano Y, Kokado Y, Sonoda T, Onishi S, Takahara S, Okuyama A, FK506-induced kidney tubular cell injury, Transplantation, 1992, 54, 1041-1047.

21) Walker RJ, Lazzaro VA, Duggin GG, Horvath JS, Tiller DJ, Evidence that alterations in renal metabolism and lipid peroxidation may contribute to cyclosporine nephrotoxicity, Transplantation, 1990, 50, 487-492.
22) Gordjani N, Epting T, Fischer-Riepe P, Greger RF, Brandis M, Leipziger J, Nitschke R, Cyclosporin-Ainduced effects on the free $\mathrm{Ca} 2+$ concentration in LLC-PK1-cells and their mechanisms, Pflugers Arch, 2000, 439, 627-633.

23) Bohme M, Jedlitschky G, Leier I, Buchler M, Keppler D, ATP-dependent export pumps and their inhibition by cyclosporins, Adv Enzyme Regul, 1994, 34, 371380. 